\title{
PENGARUH METODE PEMBELAJARAN EXAMPLE NON EXAMPLE TERHADAP PRESTASI BELAJAR MATEMATIKA SISWA KELAS VII SMP N 6 SINGARAJA
}

\author{
L.P.E.CIPTAWATI, I.M.SUGIARTA, I.M.SUARSANA \\ Jurusan Pendidikan Matematika \\ Universitas Pendidikan Ganesha Singaraja, Indonesia \\ e-mail: ekacw05@gmail.com, madesugiarta54@gmail.com, suarsanamade @gmail.com
}

\begin{abstract}
Abstrak
Penelitian ini dilaksanakan dengan tujuan untuk mengetahui apakah prestasi belajar siswa dengan metode pembelajaran Example Non Example lebih tinggi dari pada prestasi belajar matematika siswa dengan pembelajaran konvensional. Jenis penelitian ini adalah Post Test Only Control Group Desaign. Populasi pada penelitian ini adalah seluruh siswa kelas VII (non unggulan) SMP N 6 Singaraja tahun ajaran 2016/2017 dengan jumalh siswa 307 orang yang tersebar ke dalam 10 kelas. Sementara sampel penelitian diplih menggunakan multistage random sampling dan diperoleh dua kelas yaitu kelas VIIB6 sebagai kelas kontrol dan VIIB7 sebagai kelas eksperimen. Instrument penelitian yang digunakan untuk mengukur prestasi belajar matematika siswa adalah dengan menggunakan tes prestasi belajar berupa tes uraian. Berdasarkan hasil penelitian, diperoleh rata-rata skor prestasi belajar matematika untuk kelas eksperimen $=78,727$ dan kelas kontrol $=70,818$. Uji hipotesis dilakukan dengan menggunakan uji-t satu ekor, dan diperoleh nilai t-hitung $=2,030$ sementara nilai t-tabel $=1,684(\mathrm{df}=42 ; \alpha=0,05)$. Oleh karena itu, dapat disimpulkan bahwa prestasi

belajar siswa yang mengikuti metode pembelajaran Example Non Example berbantuan LKS tidak terstruktur lebih tinggi dari pada prestasi belajar siswa dengan pembelajaran konvensional.

Kata kunci : metode pembelajaran Example Non Example, LKS tidak terstruktur, prestasi belajar matematika
\end{abstract}

\begin{abstract}
This research was aimed at knowing the effect of Example Non Example implementation on student's achievement of mathematics towards $7^{\text {th }}$ grade students of SMP N 6 Singaraja. This research was a quasi experiment and used Post Test Only Control Group Design. The population of this research was all $7^{\text {th }}$ grade students (regular class) of SMP N 6 Singaraja in academic year 2016/2017 which consisted of 307 students which were distributed in 10 classes. The sample was determined by multistage random sampling and two classes were chosen as sample i.e. VIIB7 as experiment group and VIIB6 as control group. The data of student's achievement of mathematics score was collected by using the test student's achievement of mathematics in essay form. Based on the results of the research, obtaining the average skor of student's mathematics learning achievement for experiment group $=78,727$ dan for control group $=70,818$. The hypothesis testing used one tailed $t$-test, resulting the $t$ value $=2.030$ where the value of $t$-table $(d f=42 ; \alpha=0.05)$ is 1.684. Therefore, from that result can be concluded that the student's achievement of mathematics towards $7^{\text {th }}$ grade students of SMP N 6 Singaraja who learn with Example Non Example imlemented in class by is better than the student's achievement of mathematics towards $7^{\text {th }}$ grade students of SMP N 6 Singaraja who learn with conventional learning implemented.
\end{abstract}

Keywords : Example Non Example learning method, non structural student's work sheet, student's achievement

\section{Pendahuluan}

Pendidikan merupakan suatu unsur penting bagi setiap manusia. Pendidikan memiliki peran penting untuk menciptakan kehidupan yang cerdas, terbuka, dan demokratis. Oleh sebab itu pendidikan dijadikan salah satu tolak ukur dari kemajuan suatu Negara. Sehingga perlu dilakukan upaya-upaya untuk terus meningkatkan mutu pendidikan di Indonesia. Salah 
satu upaya yang telah dilakukan pemerintah adalah menyempurnakan dan memperbaharui kurikulum pendidikan yang ada.

Upaya-upaya yang dilakukan oleh pemerintah tidak hanya sekedar untuk meningkatkan mutu pendidikan, melainkan juga untuk mengatasi permasalahan-permasalahan yang ada dalam dunia pendidikan. Permasalahan yang muncul dalam dunia pendidikan dapat muncul karena berbagai faktor, baik dari pihak sekolah, guru, ataupun dari dalam diri peserta didik. Salah satu permasalahan yang muncul dari peserta didik adalah peserta didik belum dapat menerima beberapa pelajaran dengan baik, misalnya saja pada pelajaran matematika.

Matematika merupakan salah satu mata pelajaran wajib yang kurang diminati oleh peserta didik. Hal ini disebabkan karena peserta didik sering mengalami kesulitan dalam mempelajari matematika yang identik dengan kegiatan menghitung yang rumit. Pemikiran siswa tentang matematika tersebut yang menyebabkan siswa merasa kurang tertarik mempelajari matematika yang akan berdampak terhadap pencapaian prestasi belajar matematika siswa.

Pencapaian prestasi belajar matematika siswa Indonesia saat ini dinilai masih kurang. Hal ini ditunjukkan dari hasil tes PISA (Program for International Student Assessment), dimana PISA adalah studi literasi yang bertujuan untuk meneliti secara berkala tentang kemampuan siswa usia 15 tahun. Hasil tes PISA pada tahun 2015 menunjukkan bahwa dari 76 negara di dunia yang mengikuti tes tersebut, Indonesia menempati peringkat 69 (Nrl, 2013).

Rendahnya prestasi belajar matematika siswa dapat disebabkan oleh beberapa faktor. Faktor internal siswa dapat berupa rendahnya motivasi belajar dan minat siswa terhadap pembelajaran matematika. Motivasi dan minat belajar sangat diperlukan dalam mengikuti pembelajaran, seperti yang diungkapkan oleh Wardiman (dalam Sudaryono \& Rahayu, 2012), dimana siswa yang memiliki minat pada suatu mata pelajaran, maka siswa tersebut akan terdorong untuk terlibat aktif dalam kegiatan pembelajaran pada mata pelajaran tersebut. Sementara itu, faktor eksternal adalah pembelajaran yang diberikan oleh guru.

Banyak upaya yang sudah dilakukan untuk meningkatkan prestasi belajar matematika siswa, salah satunya adalah dengan menerapkan metode pembelajaran yang bervariasi untuk menciptakan pembelajaran yang kondusif. Penerapan metode pembelajaran yang sesuai dengan keadaan siswa dapat memberikan kenyamanan kepada siswa sehingga siswa dapat lebih mudah untuk memahami pembelajaran dan mencapai prestasi belajar yang lebih baik. Salah satu metode pembelajaran yang dapat membantu siswa dalam memahami pembelajaran matematika adalah metode pembelajaran Example Non Example.

Menurut Buehl (dalam Apriani,dkk : 2010) metode pembelajaran Example Non Example merupakan pendekatan proses pembelajaran yang bisa menggunakan video tentang kasus-kasus yang pernah terjadi atau gambar-gambar yang tentunya relevan dengan kompetensi dasar yang akan dicapai dalam proses pembelajaran melalui indikatorindikator yang akan digali. Sehingga peserta didik akan lebih aktif, kreatif dan bermakna dalam pembelajaran melalui audio visualnya menganalisa muatan-muatan indikator yang terkandung dalam kompetensi dasar akan dicapai. Hal ini juga sejalan dengan pendapat Haryono (2012) yang mengatakan bahwa metode pembelajaran Example Non Example merupakan metode pembelajaran dengan menggunakan media gambar untuk dianalisis oleh siswa dan menghasilkan deskripsi singkat dari suatu materi pembelajaran serta menekankan kemampuan siswa untuk menganalisis suatu konsep dari contoh dan non contoh dari materi yang dibahas. Metode Pembelajaran Example Non Example diterapkan dengan cara memberikan contoh konkrit berupa gambar-gambar dari suatu materi yang dipelajari siswa. Sehingga siswa dapat memahami materi dengan lebih mudah dan tidak membosankan. Oleh karena itu, metode pembelajaran Example Non Example dapat dijadikan sebagai alternatif yang dapat membantu siswa dalam memahami konsep-konsep dalam matematika, sehingga nantinya bisa berdampak positif terhadap prestasi belajar matematika siswa.

Metode Pembelajaran Example Non Example membelajarkan kepekaan siswa terhadap permasalahan yang ada melaluli analisis contoh dan bukan contoh yang dapat berupa gambar-gambar atau kasus yang bermuatan masalah. Dalam metode pembelajaran 
ini, guru memberikan gambar-gambar yang sesuai dengan tujuan pembelajaran yang nantinya akan dianalisis oleh siswa. Hal ini dapat membuat siswa lebih siap untuk mempelajari materi pembelajaran yang diajarkan karena siswa dilatih untuk mengklasifikasikan example dan non example dari suatu definisi konsep yang ada dalam matematika. Siswa dibiasakan untuk mampu mengkonstruksi konsep, prinsip, dan aturan menjadi pengetahuan baru, sehingga pengetahuan baru itu tidak diberitahukan oleh guru melainkan ditemukan sendiri oleh siswa. Dengan demikian, pemahaman siswa akan menjadi lebih baik sehingga siswa dapat menyerap, menguasai, dan menyimpan materi yang dipelajarinya dalam jangka waktu yang lama.

Berbeda halnya dengan metode di atas, kecenderungan metode pembelajaran yang biasa diterapkan di sekolah adalah metode pembelajaran ekspositori. Metode ekspositori adalah suatu metode penyampaian materi yang didalamnya meliputi gabungan dari metode ceramah, metode Tanya jawab, dan metode tugas (Sunaryo, 1989). Akan tetapi penerapan metode pembelajaran ekspositori di sekolah belum berjalan secara optimal. Dalam proses pembelajaran biasanya kegiatan belajar mengajar lebih berpusat pada guru (teacher centered), dan lebih menekankan pada proses penerimaan pengetahuan (materi pelajaran) bukan pada proses pencarian dan kontruksi pengetahuan, sehingga siswa menjadi pasif dan cenderung tidak memperhatikan pelajaran. Oleh karena itu, untuk membuat seluruh siswa dapat memahami materi yang dipelajari biasanya guru terpaksa harus menjelaskan kembali atau memberitahukan prosedur penyelesaian soal yang dibahas.

Proses pembelajaran konvensional yang demikian dapat membunuh keunikan siswa dan proses pembelajaran yang terjadipun menjadi kurang bermakna, karena pembelajaran hanya terarah pada satu areal saja yaitu perhitungan. Sehingga, secara teoritis dengan kurang optimalnya metode pembelajaran yang diterapkan akan berpengaruh terhadap pemahaman konsep dasar matematika siswa yang kurang optimal pula. Selanjutnya hal ini akan berimbas pada kurangnya kemampuan siswa dalam memecahkan masalah - masalah sederhana.

Berdasarkan paparan di atas, dapat diduga bahwa pemahaman matematika siswa dengan penerapan metode pembelajaran Example Non Example berbeda dengan pemahaman matematika siswa pada pelajaran matematika yang menggunakan metode pembelajaran konvensional. Sehubungan dengan itu, penulis merasa perlu dan tertarik untuk mengadakan penelitian mengenai pembelajaran matematika denga menerapkan metode Example Non Example dengan berbantuan LKS (Lembar Kerja Siswa) tidak terstruktur. Dalam kegiatan pembelajaran, siswa memerlukan sarana yang salah satunya berupa Lembar Kerja Siswa (LKS) sebagai acuan yang dapat menuntun siswa dalam memahami masalah matematika. LKS memuat sekumpulan kegiatan mendasar yang harus dilakukan oleh siswa untuk memaksimalkan pemahaman dalam upaya pembentukan kemampuan dasar sesuai indikator pencapaian hasil belajar yang harus di tempuh (Trianto, 2009). Dalam hal ini yang dimaksudkan adalah LKS tidak terstruktur karena metode pembelajaran Example Non Example merupakan metode pembelajaran yang menggunakan media gambar. LKS tidak terstruktur merupakan alat bantu mengajar yang dapat dipakai untuk mempercepat pembelajaran, memberikan dorongan belajar kepada tiap individu, dan juga memuat pentunjuk untuk mengarahkan siswa dalam kegiatan pembelajaran.

Berdasarkan uraian diatas, dipandang perlu diteliti lebih lanjut apakah ada pengaruh antara metode pembelajaran Example Non Example berbantuan LKS tidak terstruktur dengan prestasi belajar matematika siswa. Oleh karena itu, penulis tertarik melakukan penelitian dengan judul "Pengaruh Metode Pembelajaran Example Non Example Berbantuan LKS Tidak Terstruktur Terhadap Prestasi belajar Matematika Siswa Kelas VII SMP N 6 Singaraja Tahun Ajaran 2016/2017".

\section{Metode}

Jenis penelitian ini adalah penelitian semu (quasi experiment) dengan populasi seluruh siswa kelas VII (non unggulan) di SMP N 6 Singaraja yang terbagi menjadi 10 kelas yaitu Kelas VIIB1, Kelas VIIB2, Kelas VIIB3, Kelas VIIB4, Kelas VIIB5, Kelas VIIB6, Kelas VIIB7, 
Kelas VIIB8, Kelas VIIB9 dan Kelas VIIB10 dengan jumlah total seluruh siswa adalah 307 orang.

Karena keterbatasan waktu, tempat, dan biaya, penelitian terhadap populasi tidak dapat dilakukan sepenuhnya. Oleh karena itu, penelitian hanya dilakukan terhadap sebagian anggota populasi sebagai wakil dari populasi. "Bagian dari jumlah dan karakteristik yang dimiliki oleh populasi yang diteliti inilah disebut sampel” (Sugiyono, 2012). Teknik pengambilan sampel yang digunakan dalam penelitian ini adalah teknik multistage random sampling. Pengambilan sampel dalam penelitian ini dilakukan dalam dua tahap. Pada tahap pengambilan sampel pertama, akan dilakukan pengambilan sebanyak 22 siswa setiap kelasnya dengan cara pengundian. Pada tahap ini akan didapatkan 10 kelas sampel yang ukuran sampelnya sebanyak 22 siswa. Kemudian dilakukan uji kesetaraan. Setelah semua kelompok sampel setara, dilakukan pengundian untuk memilih dua kelompok untuk nantinya dijadikan kelompok sampel. Hasil pengundian adalah sebagai berikut. (1) Kelas VIIB7 sebagai kelompok eksperimen memperoleh perlakuan pembelajaran dengan metode Example Non Example, (2) Kelas VIIB6 sebagai kelompok kontrol memperoleh perlakuan dengan pembelajaran konvensional.

Variabel bebas dari penelitian ini adalah metode pembelajaran yang dipilah menjadi Example Non Example dan metode konvensional yakni metode ekspositori. Sedangkan variabel terikat dalam penelitian ini adalah prestasi belajar matematika siswa. Penelitian ini menggunakan rancangan post-test-only control group design. Dengan desain penelitian:

\begin{tabular}{l|c|c} 
Kelompok & $\begin{array}{c}\text { Variabel } \\
\text { Bebas }\end{array}$ & Post-Test \\
\hline Eksperimen & $\mathrm{X}_{1}$ & $\mathrm{Y}_{1}$ \\
\hline Kontrol & $\begin{array}{c}- \\
\text { (Arikunto,2002) }\end{array}$ & $\mathrm{Y}_{2}$
\end{tabular}

Prosedur penelitian yang dilakukan dalam penelitian ini adalah (a) Menentukan sekolah yang akan diteliti dan memilih populasi yang diteliti yaitu siswa kelas VII SMP N 6 Singaraja; (b) Orientasi dan observasi awal terhadap rancangan dan pelaksanaan pembelajaran. Penjajagan ke sekolah dengan tujuan untuk mengetahui metode pembelajaran yang digunakan pada kelas yang akan dijadikan penelitian; (c) Menentukan sampel-sampel penelitian. Menentukan sampel penelitian berupa kelas dari populasi yang telah ditentukan dan memiliki kemampuan yang setara, dengan menggunakan teknik random sampling. Sampel kelas penelitian yang diperoleh akan diundi lagi untuk menentukan kelas eksperimen dan kelas kontrol. Melakukan pengundian terhadap dua kelas sampel yang sudah dipilih sebelumnya untuk menentukan kelas eksperimen dan kelas kontrol; (d) Merancang perangkat pembelajaran matematika. Merancang perangkat pembelajaran matematika yang terdiri dari rencana pelaksanaan pembelajaran (RPP) dan lembar kerja siswa (LKS). Perangkat pembelajaran yang dirancang disesuaikan dengan metode pembelajaran yang akan digunakan, yaitu metode pembelajaran Example Non Example dan pembelajaran konvensional; (e) Mengkonsultasikan perangkat pembelajaran matematika dengan 2 orang dosen pendidikan matematika; (f) Menyusun instrumen penelitian berupa tes untuk mengetahui prestasi belajar matematika siswa; (g) Mengkonsultasikan instrumen penelitian dengan guru matematika dan 2 orang dosen pendidikan matematika; (h) Mengadakan validasi instrumen penelitian; (i) Melaksanakan pembelajaran, yaitu memberikan perlakuan pada kelas eksperimen maupun kelas kontrol. Kelas eksperimen mengikuti pembelajaran dengan metode pembelajaran Example Non Example berbantuan LKS tidak terstruktur dan siswa kelas kontrol mengikuti pembelajaran dengan metode pembelajaran konvensional; (j) Melakukan post-test pada masing-masing kelas eksperimen maupun kelas kontrol di SMP N 6 Singaraja; (k) Menganalisis hasil penelitian untuk menguji hipotesis yang diajukan; (I) Tahapan terakhir yaitu penyusunan laporan. Hasil analisis yang telah disusun kemudian diserahkan kepada dosen pembimbing untuk mendapat koreksi dan revisi seperlunya. 
Instrumen penelitian yang digunakan untuk mengukur prestasi belajar matematika siswa berupa tes dengan bentuk uraian. Untuk menghindari subjektivitas dalam memeriksa, perlu dibuatkan rubrik penskoran yang memuat semua kemungkinan jawaban siswa secara jelas sebagai pedoman dalam memeriksa.

Instrumen penelitian yang telah disusun sebelumnya diuji validitas dan reliabilitasnya melalui uji pakar untuk validitas isi dan uji coba instrumen untuk validitas dan reliabilitas tes. Uji pakar menghasilkan nilai validitas isi sebesar 1,00 yang berarti bahwa kedelapan butir soal yang diujikan berada pada kategori sangat tinggi atau dinilai sangat relevan oleh pakar.

Setelah itu, instrumen yang telah dinilai oleh pakar diujicobakan pada siswa kelas VIIIB9 SMP N 6 Singaraja semester genap tahun ajaran 2016/2017 pada tanggal 9 Mei 2017 untuk memperoleh gambaran secara empirik mengenai validitas dan reliabilitas butir soal pada instrumen penelitian. Analisis uji validitas soal menggunakan koefisien korelasi product moment dari Carl Pearson. Dari hasil analisis uji validitas butir soal tersebut diperoleh kedelapan butir soal yang diujicobakan valid. Selanjutnya analisis reliabilitas soal dilakukan dengan menggunakan rumus Alpha Cronbach. Soal yang diikutkan dalam perhitungan reliabilitas instrumen adalah soal-soal yang telah dinyatakan valid. Dari hasil pengujian reliabilitas soal diperoleh nilai koefisien reliabilitas soal sebesar 0,578 yang berarti bahwa derajat reliabilitas soal yang diujicobakan berada pada kategori sedang sehingga layak untuk dijadikan tes prestasi belajar matematika siswa. Dari hasil uji validitas dan reliabilitas tersebut maka 8 butir soal tersebut akan digunakan sebagai instrumen penelitian.

\section{Hasil Dan Pembahasan}

Data pada penelitian ini adalah skor prestasi belajar matematika siswa yang diperoleh melalui kegiatan post-test dengan menggunakan instrumen yang sebelumnya telah disusun dan telah melalui tahap uji validitas dan reliabilitas. Rangkuman statistik deskriptif data pada kelompok eksperimen dan kelompok kontrol disajikan pada Tabel 1.

Tabel 1. Rangkuman Statistik Deskriptif Data Kelompok Eksperimen dan Kelompok Kontrol

\begin{tabular}{lcc}
\hline \multicolumn{1}{c}{ Variabel } & Kelompok Eksperimen $\left(\mathbf{Y}_{\mathbf{1}}\right)$ & Kelompok Kontrol $\left(\mathbf{Y}_{\mathbf{2}}\right)$ \\
\hline$\sum_{\boldsymbol{n}_{\boldsymbol{i}}} Y_{i}$ & 138560 & 113112 \\
Mean $\left(\overline{Y_{i}}\right)$ & 22 & 22 \\
Median $(\boldsymbol{M})$ & 78,727 & 70,818 \\
Modus $(\boldsymbol{M o})$ & 79 & 70 \\
Maks & 79 & 56 \\
Min & 95 & 90 \\
Range $(\boldsymbol{r})$ & 61 & 56 \\
$\boldsymbol{s}_{\boldsymbol{i}}^{2}$ & 34 & 34 \\
$\boldsymbol{S} \boldsymbol{D}_{\boldsymbol{i}}$ & 104,970 & 132,251 \\
\hline
\end{tabular}

Analisis data untuk menguji hipotesis dilakukan dengan menggunakan Uji- $t$ satu ekor, dengan rumus:

$$
t_{\text {hit }}=\frac{\bar{Y}_{1}-\bar{Y}_{2}}{S \sqrt{\frac{1}{n_{1}}+\frac{1}{n_{2}}}}
$$

(Candiasa, 2010b)

Sebelum Uji-t dilakukan, terlebih dahulu dilakukan uji normalitas dan homogenitas data sebagai prasyarat normalitas dan homogenitas dalam melakukan Uji-t.

Perhitungan uji normalitas data prestasi belajar matematika siswa pada kelompok eksperimen dan kelompok kontrol dilakukan dengan menggunakan Uji Lilliefors. Data dikatakan berasal dari populasi yang berdistribusi normal apabila nilai $L$-hitung $<$ nilai $L$-tabel $(n ; \alpha=0,05)$. Hasil perhitungan uji normalitas dengan Uji Lilliefors tersebut diperoleh nilai $L-$ 
hitung untuk kelompok eksperimen sebesar 0,1016 dengan nilai $L$-tabel $(n=22 ; \alpha=0,05)$ sebesar 0,184 dan nilai $L$-hitung untuk kelompok kontrol sebesar 0,1293 dengan nilai $L$-tabel $(n=22 ; \alpha=0,05)$ sebesar 0,184 . Ini berarti bahwa nilai $L$-hitung baik dari kelompok eksperimen maupun kelompok kontrol sama - sama kurang dari nilai $L$-tabel, hal tersebut menunjukkan bahwa data baik dari kelompok eksperimen maupun kelompok kontrol berasal dari populasi yang berdistribusi normal.

Selanjutnya, pengujian homogenitas data dilakukan dengan menggunakan Uji Levene. Data dikatakan memiliki varian yang homogen jika nilai $W<$ nilai $F$-tabel. Dari perhitungan homogenitas data diperoleh nilai $W$ sebesar 0,183 dengan nilai $F$-tabel ( $d k$ pembilang $=1 ; d k$ penyebut $=42 ; \alpha=0,05)$ sebesar 4,08 . Jika dibandingkan, maka nilai $W<$ nilai $F$-tabel, sehingga dapat disimpulkan bahwa data pada kedua kelompok memiliki varian yang homogen.

Setelah data pada kelompok eksperimen dan kelompok kontrol dinyatakan normal dan homogen, maka pengujian hipotesis dengan menggunakan teknik Uji-t satu ekor dapat dilakukan. Pada teknik Uji- $t$ satu ekor, $H_{0}$ ditolak jika nilai $t$-hitung $>$ nilai $t$-tabel $\left(d k=n_{1}+n_{2}-\right.$ $2 ; \alpha=0,05)$ satu ekor. Dari hasil analisis data dengan menggunakan perhitungan Uji- $t$ diperoleh nilai $t$-hitung sebesar 2,030 dengan nilai $t$-tabel $(d k=42 ; \alpha=0,05)$ satu ekor sebesar 1,684. Jika dibandingkan, maka nilai $t$-hitung $>$ nilai $t$-tabel. Dengan demikian dapat disimpulkan bahwa prestasi belajar matematika siswa kelas VII SMP N 6 Singaraja yang mengikuti pembelajaran dengan metode Example Non Example lebih baik daripada prestasi belajar matematika siswa kelas VII SMP N 6 Singaraja yang mengikuti pembelajaran konvensional.

\section{Pembahasan}

Berdasarkan hasil analisis terhadap nilai prestasi belajar matematika siswa, diketahui bahwa rata-rata prestasi belajar matematika siswa pada kelompok eksperimen adalah 78,727 dan rata-rata prestasi belajar pada kelompok kontrol adalah 70,818. Uji hipotesis menggunakan Uji-t pada taraf signifikan $5 \%$ untuk nilai prestasi belajar matematika siswa diperoleh nilai statistik $t_{\text {hitung }}=2,030$, lebih dari $t_{0,05}=1,684$ dengan derajat kebebasan 42 .

Pengujian hipotesis penelitian ini bertujuan untuk melihat ada atau tidaknya perbedaan prestasi belajar matematika antara siswa yang mengikuti metode pembelajaran Example Non Example berbantuan LKS tidak tertsruktur dengan siswa yang mengikuti pembelajaran konvensional. Pengujian hipotesis ini dilakukan dengan menggunakan Uji-t (satu ekor) pada taraf signifikansi $5 \%$. Hasil yang diperoleh pada pengujian ini adalah menolak $\mathrm{H}_{0}$ dan menerima $\mathrm{H}_{a}$ yang berarti prestasi prestasi belajar matematika siswa Kelas VII SMP N 6 Singaraja yang mengikuti pembelajaran dengan metode pembelajaran Example Non Example berbantuan LKS tidak terstruktur lebih tinggi daripada prestasi belajar matematika siswa yang mendapat pembelajaran konvensional.

Rata-rata nilai tes prestasi belajar matematika siswa kelompok eksperimen lebih tinggi daripada kelompok kontrol disebabkan karena adanya metode pembelajaran Example Non Example dalam pembelajaran. Metode pembelajaran Example Non Example akan memberikan kesempatan kepada siswa untuk menemukan dan memahami konsep dengan cara menganalisis gambar-gambar yang berkaitan dengan materi pembelajaran. Siswa dapat mengkonstruksi pengetahuannya sendiri dan saling berdiskusi dengan temannya, sehingga siswa yang kurang mampu dapat bertanya kepada teman sekelompoknya, ini bertujuan untuk menanggulangi agar siswa yang kurang aktif tidak terabaikan oleh kelompoknya. Dengan saling berdiskusi siswa akan dapat memperbaiki pemahamannya. Metode pembelajaran Examples Non Examples ini merupakan metode pembelajaran yang menekankan pada keaktifan siswa dalam menganalisis gamabar-gambar/contoh dan mengeksplor kemampuannya dan berinteraksi dengan satu sama lainnya. Dengan setting pembelajaran menggunakan kelompok diskusi sangat mendorong semangat dan motivasi siswa dalam mengikuti setiap tahapan dalam pembelajaran, sehingga dapat meningkatkan prestasi belajar siswa. 
Perbedaan prestasi belajar antara kelompok kontrol dan eksperimen secara kuantitatif dapat dianalisis melalui hasil post-test prestasi belajar matematika siswa. Nilai siswa pada kelompok eksperimen yaitu kelompok yang diberikan perlakuan dengan metode pembelajaran Example Non Example cenderung lebih tinggi dibandingkan dengan nilai siswa pada kelompok kontrol. Hal tersebut disebabkan karena sebagian besar siswa pada kelompok eksperimen menunjukan antusiasme dan aktif dalam kegiatan pembelajaran ketika pembelajaran dimulai, sehingga ketika diberikan permasalahan dapat meningkatkan rasa ingin tahu mereka tinggi, dan mereka mampu menyelesaikan permasalahannya.

Pelaksanaan pembelajaran di kelas eksperimen dengan menerapkan metode pembelajaran Example Non Example dan penerapan metode konvensional pada pembelajaran di kelas kontrol sama-sama menekankan pada pencapaian prestasi belajar matematika siswa. Pada kelompok kontrol yang mendapat pembelajaran dengan pembelajaran konvensional, proses pembelajaran berjalan dengan baik. Namun tidak banyak siswa yang aktif sehingga suasana kelas juga kurang aktif. Walaupun terdapat beberapa siswa yang aktif, namun beberapa siswa yang lain cenderung hanya duduk dan mendengarkan. Ketika guru mengorganisasikan siswa untuk belajar dan mendiskusikan permasalahan yang diberikan bersama kelompoknya, siswa seringkali mengerjakan soal/masalah dalam jangka waktu yang cukup panjang mengakibatkan kurangnya waktu pembelajaran sehingga terpaksa gurulah yang harus memecahkan permasalahan tersebut dan menjelaskan materi/konsep yang seharusnya ditemukan oleh siswa sendiri. Hal ini mengakibatkan kurang terlatihnya siswa dalam menyelesaikan masalah.

Permasalahan tersebut dapat ditanggulangi dengan menerapkan metode pembelajaran Example Non Example. Pembelajaran dengan metode Example Non Example menuntut siswa untuk menganalisis materi dan mengkontruksi pengetahuannya sendiri sehingga siswa akan aktif untuk mencari dan menyelesaikan permasalahan yang telah diberikan, selain itu penggunaan gambar (sebagai contoh dan bukan contoh) sebagai bahan analisis siswa dalam penerapan metode pembelajaran Example Non Example ini juga dapat meningkatkan kemampuan dan prestasi belajar siswa, karena siswa tidak hanya dituntut untuk menyelesaikan suatu permasalahan melainkan juga menganalisis materi yang diberikan.

Dalam penerapannya metode pembelajaran Example Non Example masih mengalami beberapa kendala. Adapun kendalanya adalah tidak semua kelompok dapat aktif dan berani mencoba untuk menyelesaikan permasalahan. Kebanyakan hanya menunggu dan memperhatikan jawaban dari kelompok yang aktif. Siswa yang memiliki tingkat kognitif yang kurang cenderung diam. Oleh karena itu diperlukan peranan guru untuk membimbing siswa supaya dapat ikut berperan aktif dalam proses pembelajaran sehingga mereka yang kurang aktif tidak tertinggal. Selain itu, terdapat juga kendala ketersediaan waktu untuk menganalisi gambar-gambar yang diberikan berkaitan dengan materi yang dipelajari. Siswa yang lebih pandai dapat dengan cepat menganalisis dan memahami gambar-gambar dari materi/konsep yang diberikan sedangkan siswa yang lain masih mencoba menjawab dengan kelompoknya. Oleh karena itu, diperlukan peranan guru untuk memprioritaskan siswa-siswa yang pemahamannya kurang.

Penggunaan media pembelajaran berupa LKS tidak terstruktur sangat efektif dalam mendukung kegiatan pembelajaran. LKS tidak terstruktur yang diberikan sangat membantu guru dalam menyampaikan materi kepada siswa dengan cara membiarkan siswa tersebut menggali informasi dan mengkonstruksi pengetahuannya sendiri bersama dengan temanteman kelompoknya. LKS tidak terstruktur dapat membuat siswa berpikir untuk menemukan konsep dalam setiap materi yang dibelajarkan, sehingga siswa akan aktif berdiskusi dan menyelesaikan permasalahan yang disajikan di dalam LKS.

Temuan ini sejalan dengan penelitian yang telah dilakukan oleh Susilo (2010) bahwasannya terdapat pengaruh metode pembelajaran Examples Non Examples terhadap prestasi belajar matematika siswa kelas X SMA. Dan penggunaan metode pembelajaran Examples Non Examples dalam kegiatan belajar mengajar membuat prestasi belajar matematika lebih baik daripada pembelajaran konvensional. Siswa yang dibelajarkan dengan 
metode pembelajaran Example Non Example cenderung memperoleh prestasi belajar yang lebih tinggi dibandingkan dengan siswa yang dibelajarkan dengan menggunakan metode pembelajaran konvensional.

Berdasarkan pembelajaran yang telah dilakukan, penerapan pembelajaran dengan metode Example Non Example dapat membuat, (1) siswa lebih aktif dalam pembelajaran dan aktif mengekspresikan ide-idenya dengan menganalisis gambar-gambar yang diberikan oleh guru, (2) siswa memiliki rasa ingin tahu yang lebih tinggi, dan (3) siswa lebih bersemangat dan termotivasi untuk memecahkan masalah matematika. Hasil tersebut mendukung terjadinya peningkatan prestasi belajar matematika siswa.

\section{Simpulan Dan Saran}

Berdasarkan hasil pengujian hipotesis yang menggunakan uji-t pada taraf signifikansi 0,05 dapat ditarik kesimpulan bahwa prestasi belajar matematika siswa yang mengikuti pembelajaran dengan metode Example Non Example lebih baik daripada kemampuan prestasi belajar matematika siswa yang mengikuti pembelajaran konvensional

Peneliti maupun pihak-pihak dalam dunia pendidikan diharapkan dapat melakukan penelitian lebih lanjut mengenai metode pembelajaran Example Non Example pada aspek pembelajaran yang berbeda dan pada jenjang yang berbeda. Kepada praktisi pendidikan dapat menggunakan metode pembelajaran Example Non Example untuk diterapkan dalam pembelajaran di kelas sebagai salah satu alternatif pembelajaran matematika yang dapat meningkatkan prestasi belajar matematika siswa. Dalam praktiknya Example Non Example sudah sesuai dengan kurikulum yang berlaku saat ini. Hanya saya guru harus mempersiapkan waktu dan tenaga lebih apabila mengampu banyak kelas.

\section{Daftar Pustaka}

Apriani, Atik, dan David Indrianto. 2010. Implementasi Metode Pembelajaran Example Non Example. Sumedang : FKIP PGMI. IKIP PGRI.

Arikunto, Suharsimi. 2002. Dasar-Dasar Evaluasi Pendidikan. Jakarta: Bumi Aksara.

Candiasa, I Made. 2010b. Statistik Univariat dan Bivariat Disertai Aplikasi SPSS. Singaraja: Universitas Pendidikan Ganesha.

Haryono, Defri. 2012. Pengaruh Metode Pembelajaran Examples Non Examples Terhadap Prestasi belajar IPA Siswa Kelas IV SDN Mangunsari 04 Kecamatan Sidomukti Kota Salatiga Semester II Tahun Ajaran 2011/2012. Skripsi. Program Studi S1 Pendidikan Guru Sekolah Dasar. Universitas Kristen Satya Wacana Salatiga.

Nrl. 2013, 4 Desember. "Prestasi Belajar Matematika Dinilai Masih Kurang" detik News, http://m.detik.com/news/berita /2432402/ ini - peringkat -kemampuanmatematika-siswa-di-dunia-indonesia-nomor berapa/10\# detailfoto (diakses pada tanggal 2 September 2016).

Sudaryono, M. \& Rahayu. 2012. Pengembangan Instrumen Penelitian Pendidikan. Yogyakarta: Graha Ilmu.

Sugiyono. 2012. Statistika untuk Penelitian. Bandung: Alfabeta.

Sunaryo. 1989. Strategi Belajar Mengajar Dalam Pengajaran IImu Pengetahuan Sosial. Jakarta: DEPDIKBUD.

Susilo, Joko. 2010. Pengaruh Penggunaan Metode Mengajar Examples Non Examples Kelas $X$ Terhadap Prestasi belajar Siswa di SMA Negeri 1 Pajar Bulan Tahun Pelajaran 
Jurnal Pendidikan dan Pembelajaran Matematika Indonesia

Vol. 7 No. 1, Tahun 2018

e-ISSN : 2615-7454:

2010/2011. Skripsi. Program Studi Pendidikan Matematika. STKIP Muhhamadyah Pagaralam.

Trianto. 2009. Mendesain Model Pembelajaran Inovatif-Progesif: Konsep, Landasan, dan Implementasinya pada Kurikulum Tingkat Satuan Pendidikan (KTSP). Jakarta: Kencana Prenada Media Group. 